\title{
The admissibility of evidence in criminal proceedings between European Union Member States
}

\author{
Charlotte Claverie-Rousset $^{\star}$
}

The possibility to use criminal evidence within the European Union raises a lot of practical difficulties. While the question of searching and obtaining transnational evidence is a real matter of concern for the European Council - which again recently suggested a project for a Directive on the European Investigation Order in criminal matters - there is no proper regulation on the admissibility of such evidence. Though, in order to ensure efficient repression of cross-border offences, it is necessary to determine the manner in which a piece of evidence obtained in a Member State will be admissible before another Member State's criminal court. The principle of mutual recognition may settle this matter of the admissibility of criminal evidence between Member States but this method is not self-sufficient and its efficiency depends on the creation of common rules in this area.

\section{Introduction}

(1) Gathering and admissibility of the evidence - "Evidence lawfully gathered by one Member State's authorities should be admissible before the courts of other Member States, taking into account the standards that apply there". This key idea, expressed in the Tampere Conclusions of $1999^{1}$, already highlighted practical difficulties in using criminal evidence obtained abroad, more specifically in another European Union Member State. For example, is criminal evidence collected in Spain admissible before a French criminal court? As of 2012, this matter obviously still remains.

If the question of searching and obtaining transnational evidence was a real matter of concern for the European Council, the one fundamental issue of the admissibility of such evidence was, on the contrary, strongly neglected. This lack of regulation is regrettable because all of the instruments created to encourage the international searching of evidence is only efficient if the evidence obtained is exploitable in another Member State.

(2) Fragmentation of judicial cooperation instruments concerning the gathering of evidence in criminal matters - Cooperation with foreign authorities is essential in order that the dispersion of evidence (documents, objects, information, testimonies, etc) between European Union Members States does not interfere with repression of offences committed in one state. This pre-trial phase in judicial cooperation is therefore as fundamental as the others.

However, this cooperation is not made easier by existing regulations for obtaining criminal evidence within the EU because there are two types of instruments. Firstly,

\footnotetext{
${ }^{\star}$ Professor in French Criminal Law, University of Bordeaux.

${ }^{1}$ European Council of 15-16 October 1999, Conclusions of the Presidency - SN 200/1/99 REV 1. § 36.
} 
there are instruments based on the principle of mutual assistance, the European Convention on Mutual Assistance in Criminal Matters', supplemented by the Schengen Agreement and the Convention on Mutual Assistance in criminal matters $^{3}$, and by the 2000 Convention on Mutual Assistance ${ }^{4}$. Secondly, there are instruments based on the principle of mutual recognition, most notably the Framework Decision on the execution in the EU of orders freezing property or evidence ${ }^{5}$ and the Framework Decision on the European Evidence Warrant (EEW) ${ }^{6}$.

It is possible to state a juxtaposition of those different instruments because both the Framework Decision on orders freezing property and the one on the European Evidence Warrant add themselves to the instruments of judicial cooperation already in application ${ }^{7}$. This juxtaposition generates a double fragmentation. The first one concerns the type of evidence. A European Evidence Warrant can only be issued in order to obtain evidence that already exists and is directly available in the form of items, documents or data. Owing to this limited scope of application, a European Evidence Warrant cannot, for example, be issued for the purpose of interviewing suspects or witnesses or for obtaining information in real time, such as interception of communications or monitoring of bank accounts, as these types of evidence although directly available - do not already exist. Nor can a European Evidence Warrant be issued for purposes such as conducting analyses of existing objects, documents, or data, or through obtaining bodily material like DNA samples or fingerprints, as these types of evidence - although already existing - are not directly available without further investigation or examination. The European Evidence Warrant is therefore not used by judicial authorities who turn to previous judicial cooperation $^{8}$.

The second fragmentation is related to the searching of evidence. Indeed, the framework decision on the execution in the EU for orders freezing property or evidence aims to prevent any operation of destruction, transformation, removal, transfer, or alienation of evidence; but its scope is limited to the phase of freezing and does not concern transfer of evidence orders which must be done by classic judicial cooperation.

The coexistence of those cooperation instruments, announced in 2008 as "transitional until, in accordance with the Hague Programme, the types of evidence-

\footnotetext{
${ }^{2}$ European Convention of 20 April 1959 on mutual assistance in criminal matters.

${ }^{3}$ Convention of 19 June 1990 implementing the Schengen Agreement of 14 June 1985 between the Governments of the States of the Benelux Economic Union, the Federal Republic of Germany and the French Republic on the gradual abolition of checks at their common borders.

${ }^{4}$ Convention of 29 May 2000 on mutual assistance in criminal matters between the Member States of the European Union (2000/C 197/01), and its Protocol of 16 October 2001 (2001/C 326/01).

${ }^{5}$ Council Framework Decision of 22 July 2003 on the execution in the EU of orders freezing property or evidence (2003/577/JHA). See J. Pradel, G. Corstens, G. Vermeulen, Droit pénal européen, Dalloz, 3rd edition, 2009, no 583 et seq.; A. Beziz-Ayache, "La nouvelle procédure de gel de biens ou d'éléments de preuve", Actualité juridique pénal 2005, page 410 et seq.

${ }^{6}$ Council Framework Decision of 18 December 2008 on the European Evidence Warrant for the purpose of obtaining objects, documents and data for use in proceedings in criminal matters (2008/978/JHA).

${ }^{7}$ Council Framework Decision of 18 December 2008 on EEW, Article 21(1).

${ }^{8}$ Information Report on the creation of a European Public Prosecutor's Office of 29 June 2011, registered at the French Assemblée Nationale and presented by Mr. Guy Geoffroy and Mrs Marietta Karamanli.
} 
gathering excluded from the scope of this Framework Decision are also the subject of a mutual recognition instrument, the adoption of which would provide a complete mutual recognition regime to replace mutual assistance procedures", , remains.

(3) The Lisbon Treaty - At the same time, entry into force of the Lisbon Treaty, article $82 \S 2$ of the Treaty on the Functioning of the European Union (TFEU) says that "to the extent necessary to facilitate mutual recognition of judgments and judicial decisions and police and judicial cooperation in criminal matters having a cross-border dimension, the European Parliament and the Council may, by means of directives adopted in accordance with the ordinary legislative procedure, establish minimum rules. Such rules shall take into account the differences between the legal traditions and systems of the Member States. They shall concern mutual admissibility of evidence between Member States [...]". However, this possibility of establishing minimum rules has not been exploited yet.

(4) The Green Paper of 2009 - Aware of difficulties of circulation of criminal evidence between EU Member States, the European Commission published a green paper in November 2009, on obtaining evidence in criminal matters from one Member State to another and securing its admissibility ${ }^{10}$. This green paper considers creating a unique instrument based on mutual recognition which would cover all types of evidences. It says that "the aim, in relation to orders for the purpose of obtaining evidence, is to ensure that the evidence is admissible, to prevent its disappearance and to facilitate the enforcement of search and seizure orders, so that evidence can be quickly secured in a criminal case" 11 . The green paper adds that "the existing instruments on obtaining evidence in criminal matters already contain rules aimed at ensuring the admissibility of evidence obtained in another Member State, i. e. to avoid evidence being considered inadmissible or of a reduced probative value in the criminal proceedings in one Member State because of the manner in which it has been gathered in another Member State. However, these rules only approach the issue of admissibility of evidence in an indirect manner as they do not set any common standards for gathering evidence. There is therefore a risk that the existing rules on obtaining evidence in criminal matters will only function effectively between Member States with similar national standards for gathering evidence"12. Thus, while emphasizing the deficiencies of actual regulations which treat the matter of admissibility only indirectly, this green paper highlights the necessity of a harmonisation of States Members' legislations, without putting forward concrete measures.

(5) The Stockholm Programme - Only a few weeks after the green paper was published, the European Council agreed, in the Stockholm Programme adopted on 11 December, $2009^{13}$, to pursue works that should allow the establishment of a global system of obtaining evidences in European cases, on the grounds

\footnotetext{
${ }^{9}$ Council Framework Decision of 18 December 2008 on EEW, § 25 .

${ }^{10}$ COM (2009) 624 final.

$11 \S 2$.

$12 \S 4.2$.

${ }^{13}$ Programme entitled "An open and secure Europe serving and protecting the citizens". See conclusions of the Europen Council of 10 and 11 December 2009 (EUCO 6/09).
} 
of mutual recognition. It indicated that existing instruments in this area are fragmentary and that a new approach is necessary, which must be based on the principle of mutual recognition, while taking into account the flexibility of the classic judicial cooperation. The European Council thus wished a global system aimed to replace all previous instruments in this area ${ }^{14}$.

(6) Project of a Directive on the European Investigation Order - A project of a Directive on the European Investigation Order (EIO) in criminal matters has been suggested ${ }^{15}$ in order to fulfil these expectations. The EIO is a judicial decision issued by a competent authority of a Member State in order to have one or several specific investigative measure(s) carried out in another Member State with a view to gathering evidence. The project posed some serious issues, mainly regarding the grounds for refusal, and the will of some Member States to introduce a control of the double criminality. At its meeting on 13 and 14 December 2011, the Council arrived at a general approach on the text of the Draft Directive, even if some delegations maintain parliamentary scrutiny reservations on the Draft Directive ${ }^{16}$.

In practical terms, the Draft Directive establishes a global system destined to replace all instruments actually existing in this area. The EIO has a horizontal scope and therefore applies to almost all investigative measures. However, some measures require specific rules which are better dealt with separately, such as the setting up of a Joint Investigation Team (JIT) and the gathering of evidence within a JIT as well as some specific forms of interception of telecommunications (interception with immediate transmission and interception of satellite telecommunications). Existing instruments should continue to apply to these types of measures ${ }^{17}$. The Draft Directive creates a single instrument making easier the gathering and obtaining of criminal evidence, in order to put an end to fragmentation ${ }^{18}$, and suggests a harmonisation of cooperation methods. On the other hand, while the matter of the admissibility of such evidence remains settled, it becomes increasingly urgent to

\footnotetext{
14 That was recommended by several authors, who criticize this "divided approach" which "does not match with the logic of a criminal investigation” (D. Flore, Droit pénal européen. Les enjeux d'une justice pénale européenne, Larcier, 2009, page 395). See also J. Lelieur, "L'application de la reconnaissance mutuelle à l'obtention transnationale de evidences pénales dans l'Union européenne : une chance pour un droit probatoire français en crise", Revue de science criminelle et de droit pénal comparé 2011, page 1.

${ }^{15}$ Initiative for a Directive of the European Parliament and of the Council regarding the European Investigation Order in criminal matters of the Kingdom of Spain, the Kingdom of Belgium, the Republic of Estonia, the Republic of Bulgaria, the Republic of Austria, the Republic of Slovenia and the Kingdom of Sweden, proposed on 21 May, 2010, (Interinstitutional file 2010/0817 COD).On this project, see M. Marty, "Un exemple de décision nouvelle : la décision d'enquête européenne", Jurisdoctoria no 7, 2011, p. 117 (http://www.jurisdoctoria.net/pdf/numero7/ NUMERO_7.pdf) ; S. Manacorda, "Le droit pénal sous Lisbonne : vers un meilleur équilibre entre liberté, sécurité et justice ?", Revue de science criminelle et de droit pénal comparé 2011, page 945 et seq.; L. Priou-Alibert, "La collecte des preuves : vers un régime européen commun. Projet de directive concernant la décision d'enquête européenne en matière pénale", Dalloz actualité 9 septembre 2010.

${ }^{16}$ See the consolidated text of the draft Directive agreed as a general approach (interinstitutional file 2010/0817 COD, document no 18918/11).

${ }^{17}$ The EIO provides a single regime for obtaining evidence. Additional rules are, however, necessary for some types of investigative measures which should be included in the EIO, such as the temporary transfer of persons held in custody, hearing by video or telephone conference, obtaining of information related to bank accounts or banking transactions or controlled deliveries.

${ }^{18}$ See supra no 2. Actually, this fragmentation is mentioned in the introduction of the project of the Directive.
} 
legislate in this area ${ }^{19}$. It is necessary to ensure efficient repression of cross-border offences and respect of the citizens fundamental rights.

(7) Method - It is almost certain that the matter of the admissibility of criminal evidence between Member States will be settled thanks to the principle of mutual recognition. The evolution of judicial cooperation instruments in criminal matters is indeed based on the almost systematic application of this method in various areas, such as the European Arrest Warrant ${ }^{20}$, financial penalties ${ }^{21}$, confiscation orders ${ }^{22}$, custodial sentences, or measures involving deprivation of liberty ${ }^{23}$ as well as judgements and probation decisions with a view to the supervision of probation measures, alternative sanctions ${ }^{24}$, and searching evidence ${ }^{25}$. Nevertheless, as practical and efficient as it is, the method of mutual recognition is not inevitably applicable to the admissibility of criminal evidence, at least, not per se (II). The differences of legislation in criminal proceedings that exist between Member States obstruct the mutual confidence essential for the functioning of this method. Consequently, the mutual recognition of criminal evidence needs to go through the creation of common rules on the admissibility of such evidence (III).

\section{Deficiencies of mutual recognition to ensure the admissibility of evidence in criminal matters between European Union Member States}

(8) Assets and weaknesses of mutual recognition - At the Tampere Summit, the European Council wished that mutual recognition became "the cornerstone of judicial co-operation in both civil and criminal matters within the Union" ${ }^{\text {, }}$, and the Stockholm Programme intended to spread the scope of mutual recognition even more. Mutual recognition is then, a priori, the best method to ensure the admissibility of criminal evidence within the Union. Nevertheless, this method cannot apply efficiently to criminal evidence without adaptation (1); and despite this adaptation, weaknesses of mutual recognition remain, and make its implementation in this area more difficult (2).

\footnotetext{
${ }^{19}$ See the Information Report on the creation of a European Public Prosecutor's Office of 29 June 2011, registred at the French Assemblée Nationale, op. cit.

${ }^{20}$ Council Framework decision 2002/584/JHA of 13 June 2002 on the European arrest warrant and the surrender procedures between Member States. In French Criminal Law, see Article 695-11 et seq. Code de procédure pénale.

${ }^{21}$ Council Framework decision 2005/214/JHA of 24 February 2005 on the application of the principle of mutual recognition to financial penalties, modified by the Council Framework Decision 2009/299/JHA of 26 February 2009 .

${ }^{22}$ Council Framework decision 2006/783/JHA of 6 October 2006 on the application of the principle of mutual recognition to confiscation orders.

${ }^{23}$ Council Framework decision 2008/909/JHA of 27 November 2008 on the application of the principle of mutual recognition to judgments in criminal matters imposing custodial sentences or measures involving deprivation of liberty for the purpose of their enforcement in the European Union, modified by the Council Framework Decision 2009/299/JAI of 26 February 2009.

${ }^{24}$ Council Framework decision 2008/947/JAI of 27 November 2008 on the application of the principle of mutual recognition to judgements and probation decisions with a view to the supervision of probation measures and alternative sanctions.

25 See supra no 2.

${ }^{26}$ European Council of 15-16 October 1999, Conclusions of the Presidency - SN 200/1/99 REV 1. § 33.
} 


\section{Necessity to adapt mutual recognition to apply to the admissibility of criminal evidence}

(9) Lack of control of the admissibility of evidence - According to some authors, "if we want to fight efficiently cross-border crime, the simpler method is to impose mutual recognition of admissibility of evidence" 27 . It is true that this method appears to be efficient because it implies the lack of control of the admissibility of the evidence obtained abroad (a). But if mutual recognition enables obtention of evidence, it cannot ensure its admissibility, so that in this area of criminal evidence, it must be combined with the application of the forum regit actum rule (b).

\section{a) Lack of control of the admissibility of the evidence obtained abroad}

(10) The principle of mutual recognition - The application of mutual recognition to criminal evidence is not obvious. Indeed, it concerns traditionally judicial decisions ${ }^{28}$, and furthermore, mutual recognition is "the fact that a judicial decision taken in a member State, according to its rules, shall be executed without any further formality being required in any other member State, as if it was a decision from this second State"29. In other words, the mutual recognition consists "for the authorities of a State, to acknowledge the same effects to foreign decisions as to national decisions, in spite of the opposing differences of their legal orders" ${ }^{\prime 3}$. As such, mutual recognition means no exequatur of the decision, that is to say no "judicial authorization to execute, granted to a jurisdictional or gracious act, deprived of executing force in the legal order of the required judge" 31 because the decision is granted with a "European executive force" $"$. The decision taken in a Member State is therefore granted, not only with national executive force but with European executive force, because a specific act of exequatur is useless. Because of the lack of control, the circulation of justice decisions is faster and ensures the efficiency of criminal proceedings.

(11) The application of mutual recognition to admissibility of criminal evidences - Applied to the admissibility of evidences, mutual recognition would

${ }^{27}$ J.-P. Zanoto, "Les nouvelles démarches tendant à améliorer la coopération : aspects pratiques ", in L'espace judiciaire européen, Actes du colloque organisé en Avignon le 16 octobre 1998, La documentation française, 1999, p. 136.

28 This ambiguous terminology should not hide that administrative decisions inter in the scope of mutual recognition instruments in the same way that judicial authorities decisions. That is the reason why some authors prefer to evoke jurisdictional acts (G. Taupiac-Nouvel, Le principe de reconnaissance mutuelle des décisions répressives dans l'Union européenne. Contribution à l'étude d'un modèle de libre circulation des décisions de justice, Librairie Générale de Droit et de Jurisprudence, Fondation Varenne, collection de thèses volume 50, 2011, § 184 et seq.).

${ }^{29}$ D. Flore, "Reconnaissance mutuelle, double incrimination et territorialité", in La reconnaissance mutuelle des décisions judiciaires pénales dans l'Union européenne, (directed by G. de Kerchove and A. Weyembergh), Bruxelles, Editions de l'Université de Bruxelles, 2001, p. 75.

${ }^{30}$ F. Tulkens, "La reconnaissance mutuelle des décisions sentencielles. Enjeux et perspectives", in La reconnaissance mutuelle des décisions judiciaires pénales dans l'Union Européenne, Université de Bruxelles, IEE, 2001, p. 168.

${ }^{31}$ Vocabulaire juridique, sous la direction de G. Cornu, Association Henri Capitant, 9ème éd., Presses Universitaires de France, Quadrige, 2011.

${ }^{32}$ F. Jault-Seseke and J. Lelieur, "Les différences d'approche de l'espace judiciaire européen sur les plans civil et pénal”, in L'espace judiciaire européen civil et pénal : regards croisés, Dalloz, collection Thèmes et commentaires, 2009, page 15 . 
work depending on two steps. First, the executing state shall recognize without formality the searching decision and whether it is an EEW or an $\mathrm{EIO}^{33}$. This is a classic application of the mutual recognition to a judicial decision because issuing such a warrant presupposes, before all else, a national jurisdictional decision ${ }^{34}$. Once the evidence is obtained in the executing State, the issuing State shall receive and use the evidence gathered without controlling its admissibility because it must reciprocally recognize the acts made by the executing state. Then, since mutual recognition consists of recognizing the foreign decision and admitting as true what has been certified valid in the partner state ${ }^{35}$, national jurisdictions of the issuing States shall not be competent to verify the admissibility of the evidence obtained in the executing State. In other words, every evidence legally gathered in a member state should be admissible in every other state, without any verification from the criminal jurisdiction which intends to use it. It is obviously legal fiction that the jurisdiction which receives the evidence accepts it as if it was legally collected according to its own legal procedures. Nevertheless, the matter of mutual recognition of evidence is far different from the one of mutual recognition of a judicial decision. Indeed, the evidence received is not a foreign judicial decision having a "presumption of validity." As a result, it is not opportune for the issuing State to recognize automatically the admissibility of the evidence obtained in the executing State as it has not been controlled by this one ${ }^{37}$.

(12) Interest of mutual recognition compared with the classic judicial cooperation - Despite these reservations, the method of mutual recognition is unquestionably more efficient than classic judicial cooperation. When the requesting state makes a request for mutual assistance to the requested State which ultimately transfers the evidence, it is the jurisdiction of the requesting state to declare itself competent or not to control its admissibility. In France, the criminal chamber of the Cour de cassation established a distinction whether France is the requesting or the requested State. In the first case, if the evidence was obtained in another member state but is produced before a French penal court, it is considered not competent ${ }^{38}$, so the admissibility of the evidence can only be controlled by the requested State. France applies mutual recognition without saying it. In the second case, when the evidence was obtained in France to be used in another member state, French criminal jurisdictions claim themselves competent to verify that the evidence was gathered according to the French legislation in force. In both cases, it

\footnotetext{
${ }^{33}$ Obviously, mutual recognition does not apply to traditional judicial cooperation (based on the Convention of 29 May, 2000: see supra, note 2) which, by definition, is not a cooperation instrument.

${ }^{34}$ About the EEW, Article 2(c) of the Framework Decisions defines the issuing authority as "a judge, a court, an investigating magistrate or a public prosecutor competent in the case concerned". The same definition is given by Article 2(a) of the Project of Directive on the EIO.

${ }^{35}$ About this "reception" procedure, see G. Taupiac-Nouvel, Le principe de reconnaissance mutuelle des décisions répressives dans l'Union européenne. Contribution à l'étude d'un modèle de libre circulation des décisions de justice, op. cit., $\S 428$ et seq.

${ }^{36} \mathrm{G}$. Taupiac-Nouvel, Le principe de reconnaissance mutuelle des décisions répressives dans l'Union européenne. Contribution à l'étude d'un modèle de libre circulation des décisions de justice, op. cit., §220 et seq.

${ }^{37}$ See infra, no 33 et seq.

${ }^{38}$ Cour de cassation, chambre criminelle, 24 June, 1997 (Bull. crim. n²52).
} 
is possible that the partner state adopts the same position, so that it could potentially lead to conflicts of competencies, positive, in the first case, negative in the second.

The lack of mutual recognition in the classic mutual assistance procedures generates some difficulties. Nevertheless, the application of mutual recognition to criminal evidences can raise matters in the use of such evidence.

(13) Difficulties of use of the evidence obtained thanks to mutual recognition - If mutual recognition seems to be efficient because it means no jurisdictional control from the issuing State on the admissibility of the evidence obtained in the executing State, it could raise some practical difficulties. Indeed, "the matter of the admissibility of the evidence transferred to the issuing State might be raised because it has been obtained in conditions which violate the issuing State legislation. In this case, mutual recognition would admittedly work because it would allow the evidence to be obtained, but it is useless if this evidence is not then admissible afterwards. It is possible to avoid this pitfall by allowing the issuing State to indicate in advance which procedural rules in searching for evidence are essential and which must be absolutely respected" 39 . It is already an adaptation of mutual recognition which means, in theory, the respect of each legal tradition. Mutual recognition is accompanied by the possibility of applying the issuing States' legislation in the executing States: that is, the rule forum regit actum.

\section{b) Lack of control combined with the forum regit actum principle}

(14) Forum regit actum and locus regit actum - As a rule, evidence shall be gathered according to the requested state law (locus regit actum). But, in order to compensate for the eventual differences of legislation on criminal proceedings between the issuing State and the executing State, investigation acts and gathering of evidence can sometimes been done according to the issuing State laws (forum regit actum). Mutual recognition is then adapted to the special features of criminal evidence. By allowing the application of the issuing State law, evidence collected in the executing State will be perfectly admissible in the issuing State because, by definition, they would have been collected according to its formalities. Solutions on this matter are quite similar, in spite of the diversity of existing instruments.

(15) Classic judicial cooperation - Recent texts are implementing this process for procedural laws that then allow a direct application of a foreign law in criminal matters ${ }^{40}$. For example, the Convention on Mutual Assistance in criminal matters between the Member States of the European Union asserts the principle of execution of assistance requests according to the requesting state law, whereas they are

\footnotetext{
${ }^{39}$ V. Malabat and alii, "La dimension internationale de la justice pénale", Rapport de recherche, Mission Droit et Justice, November, 2011, page 188.

${ }^{40}$ This solution being exceptional in criminal matters, some authors noticed that "criminal courts cannot apply a foreign Criminal Law" (D. Rebut, Droit pénal international, Précis Dalloz, 1ère éd., 2012, § 28, page 23. On the contrary, others admit that a foreign Criminal Law could be applied by a criminal court in some cases (see A. Huet et R. Koering-Joulin, Droit pénal international, Presses Universitaires de France, collection Thémis, 3rd edition, $2005, \S 114$ et seq.)
} 
traditionally executed according the executing state law ${ }^{41}$. According to Article 4(1) of the Convention of 29 May 2000, "where mutual assistance is afforded, the requested Member State shall comply with the formalities and procedures expressly indicated by the requesting Member State, unless otherwise provided in this Convention and provided that such formalities and procedures are not contrary to the fundamental principles of law in the requested Member State".

(16) European Evidence Warrant - The executing authority shall recognise an EEW without any further formality being required and shall forthwith take the necessary measures for its execution in the same way that an authority of the executing state would obtain the objects, documents or data ${ }^{42}$. In theory, the executing state has, therefore, complete freedom since it shall "be responsible for choosing the measures which under its national law will ensure the provision of the objects, documents or data sought by an EEW and for deciding whether it is necessary to use coercive measures to provide that assistance. Any measures rendered necessary by the EEW shall be taken in accordance with the applicable procedural rules of the executing state" 43 . In other words, the issuing State asks for an aim, and the executing authority chooses the resources to achieve this. It seems like a classic and absolute application of the locus regit actum rule. But the execution authority freedom is not complete because according to Article 12 of the Framework Decision, "the executing authority shall comply with the formalities and procedures expressly indicated by the issuing authority unless otherwise provided in this Framework Decision and provided that such formalities and procedures are not contrary to the fundamental principles of law of the executing State". For example, no one can be forced to give objects, documents or data liable to incriminate himself, etc.

(17) European Investigation Order - The draft Directive says that "the executing authority shall comply with the formalities and procedures expressly indicated by the issuing authority unless otherwise provided in this directive and provided that such formalities and procedures are not contrary to the fundamental principles of law of the executing state" ${ }^{, 44}$.

(18) Critics - This possibility of gathering evidence in the executing State according to the issuing State law does not have unanimous backing. Some authors consider that this solution is not appropriate because it is not only questionable with regard to the legality principle, but it would not ensure the efficiency of the cooperation $^{45}$. Indeed, it is not certain that this procedure will guarantee the admissibility of the evidence obtained abroad. The issuing authority will, when sending the warrant or the investigation order, have to anticipate potential legal difficulties, a task which seems particularly heavy to undertake, because it implies

\footnotetext{
${ }^{41}$ A. Weyembergh, "L'avenir des mécanismes de coopération judiciaire pénale entre les Etats membres de l’Union européenne", in Vers un espace judiciaire pénal européen (directed by G. de Kerchove and A. Weyembergh), Université de Bruxelles, IEE, 2000, page 147.

42 Council Framework Decision of 18 December 2008 on the EEW, Article 11(1).

${ }^{43}$ Council Framework Decision of 18 December 2008 on the EEW, Article 11(2).

${ }^{44}$ Project of a Directive on the EIO, article 8(2).

${ }^{45} \mathrm{G}$. Taupiac-Nouvel, Le principe de reconnaissance mutuelle des décisions répressives dans l'Union européenne. Contribution à l'étude d'un modèle de libre circulation des décisions de justice, op. cit., § 214 et seq.
} 
foreseeing which gathering mode seems more adequate. It can be really hard for the issuing authority to ask for the execution of a specific measure in view of obtaining evidence since, by definition, it is not on the spot, and might not choose the better adapted investigation measure. Besides, the question of admissibility can be raised again when, for example, a piece of evidence is collected thanks to a house search whereas the issuing State requested a questioning. It is indeed conceivable that the issuing State specified precise rules for questioning, as allowed by the different instruments, but that the executing State decided to carry out a search. More generally, the existing system does not state who can control the application of the issuing State law by the executing State ${ }^{46}$.

The application of the issuing State law by the executing State does not remove the difficulties of mutual recognition in the absence of a harmonisation of legislations on criminal proceedings. If this method applies efficiently to today's judicial decisions, it seems on the other hand inadequate, despite the adaptations planned, to guarantee the admissibility of criminal evidence.

\section{Weaknesses of the application of mutual recognition to the admissi- bility of criminal evidence}

(19) Invincible differences in criminal proceedings - Advantages of mutual recognition are considerable and this method works very well for the circulation of judicial decisions but not necessarily for evidence. Mutual recognition comes up against the differences of legislations between member states, differences which can ruin the mutual confidence necessary for the implementation of mutual recognition (a). Besides, those differences might lead to ill-advised use of mutual recognition, that is to say for diverting the procedures (b).

\section{a) Differences of legislations obstructing the admissibility of criminal evidence}

(20) The necessity of mutual confidence - The existing differences in criminal proceedings between the European Union Member States widely obstructs the admissibility of evidence. If this was already true in a Union with only fifteen members, it is even truer today with twenty-seven member states. The differences of legislations create mistrust between states, mistrust which prevents mutual recognition $^{47}$. The fear of receiving evidence which has been collected thanks to unusual procedures might provoke its inadmissibility.

\footnotetext{
${ }^{46}$ On this matter, see infra no 35.

${ }^{47}$ European institutions are aware of the necessity to establish a mutual confidence between the member States. For example, the programme of measures to implement the principle of mutual recognition of decisions in criminal matters adopted by the Council in December, 2000, (document 2001/C 12/02) points out that "implementation of the principle of mutual recognition of decisions in criminal matters presupposes that Member States have trust in each others' criminal justice systems". Moreover, Council Framework Decisions on the European Arrest Warrant and on the EEW states that "the principle of mutual recognition is based on a high level of confidence between Member States" (respectively $\S 10$ of the Framework Decision of 13 June 2002 and $\S 8$ of the Framework Decision of 18 December 2008).
} 
In the same way that a judge facing a European Arrest Warrant from a system in which prisons are dubious, fraught with penalties or slowness of proceedings might diligently control the warrant validity, it is conceivable to think that a judge considering evidence obtained in a country whose criminal proceedings are considered, rightly or wrongly, as showing little respect for human rights, might declare the evidence inadmissible, even if it was obtained in acceptable conditions. And yet differences of legislations might negate this mutual confidence.

(21) The legal context of obtention of the evidence - In most cases, it is less the evidence itself which can be contested (DNA, document, blood test, etc) than the way is was obtained. The main question is can we, in a state, give legal validity to evidence gathered in the legal context of another state if the foreign legal context around the evidence is sensitive in the state of recognition. Logically, the interest of mutual recognition is to remove obstacles from this foreign legal context, and yet, paradoxically, the main instrument of mutual recognition concerning evidence, the EEW, applies to evidence which practically lacks legal context $^{48}$. It appears that mutual recognition cannot remove the differences of legislation in criminal proceedings between member states. These differences concern mainly three elements: the role of the criminal judge in searching and gathering evidence, admissible evidence, and mostly, the respect of guarantees granted to the defendant.

(22) The role of the criminal judge in searching the evidence - Firstly, mutual confidence between several states can be weakened if their legal systems are based on different legal traditions. Whereas in Common Law countries, procedure is classically considered as accusatory, in Romano-Germanic countries, it is rather inquisitorial. Even if this distinction is not quite true today, because all systems are mixed $^{49}$, these cultural differences might sometimes cause mistrust between states. But it is nothing compared, for example, to the existing concerns about the judge's independence from the executive power ${ }^{50}$, etc.

(23) Admissible evidence - Moreover, the admissibility of criminal evidence between member states might be placed in jeopardy by the differences concerning the type of evidence that is admissible. Indeed, if in France, for example, the evidence is free and can be established by any means - subject to respecting legal formalities- some states might refuse certain kinds of evidence, such as the United Kingdom which, in principle, excludes hearsay evidence. Besides, in some states, it is possible to use a piece of evidence in a procedure obtained by committing an

\footnotetext{
${ }^{48} \mathrm{~J}$. Lelieur, "L'application de la reconnaissance mutuelle à l'obtention transnationale de evidences pénales dans l'Union européenne : une chance pour un droit probatoire français en crise", op. cit., $\S 20$.

${ }^{49}$ A. Weyenbergh, L'harmonisation des législations : condition de l'espace pénal européen et révélateur de ses tensions, éditions de l’Université de Bruxelles, collection Etudes européennes, 2004, § 142.

50 The delicate question of the French Prosecutor's status has, for example, led to a condemnation by the European Court of Human Rights (ECHR 5th section, 23 November, 2010, Moulin versus France, no 37104/06 ; Recueil Dalloz 2011, page 26 note F. Fourment, page 277 note J.-F. Renucci, and page 338 note J. Pradel ; Revue de science criminelle et de droit pénal comparé 2011, page 208 note D. Roets).
} 
offence (which was not committed by a policeman), whereas it is impossible in other states ${ }^{51}$, etc.

(24) Protection of fundamental rights - Finally, the application of mutual recognition to a piece of evidence obtained in a member state is hardly acceptable if the state does not really protect fundamental rights, such as defence rights and a fair trial. Instruments actually in force intend to respect "the fundamental rights and the principles recognised by Article 6 of the Treaty on the European Union and reflected by the Charter of Fundamental Rights of the European Union, notably Chapter VI thereof" ${ }^{\prime \prime}$. Obviously, some rights recognised by this charter are only pertinent within the context of the obtention of criminal evidence: the prohibition of torture and inhuman or degrading treatment or punishment, protection of personal data, presumption of innocence, defence rights, etc. Nevertheless, in spite of these principles, some member states, one of which is France, do not respect fundamental rights and are sometimes sentenced by the European Court of Human Rights.

In concrete terms, we can wonder if, in the application of mutual recognition, the requesting state which obtained a biological sample done without the consent of the defendant, although its legislation requires such consent, will consider this evidence admissible. The same question can be raised concerning a questioning statement of a suspect who was not notified of their rights. Examples could be declined infinitely and the obligation for the requested state to respect formalities defined by the requesting state cannot settle these difficulties.

Consequently, with regard to the differences of criminal proceedings in the twenty-seven member states, it is unlikely to apply mutual recognition to the admissibility of evidence because the lack of control of admissibility from the issuing State's criminal judges means admitting the admissibility of a piece of criminal evidence obtained abroad according to rules that potentially oppose the national rules. Besides, in the actual state in which the laws are national, without prior harmonisation of criminal proceedings, mutual recognition might provoke the misuse of proceedings.

\section{b) Risks of ill-advisedly use of mutual recognition}

(25) Incorrect use of procedural weaknesses - If we were to apply mutual recognition to criminal evidence, some states might divert this procedure to obtain evidence in a member state which is less scrupulous about, for example, fundamental rights, and then use mutual recognition in order for the evidence to be admissible in its national procedure.

This problem has been raised in the draft Framework Decision on the EEW of 14 November, 2003. According to this text, objects, documents or data may have a

\footnotetext{
${ }^{51}$ See the conclusions of the 2nd International Congress of French-speaking Penal jurists organised by the University Montesquieu-Bordeaux IV (3 and 4 May 2012) on the theme of "La preuve pénale. Problèmes contemporains en droit comparé", éditions l'Harmattan, 2012.

${ }^{52}$ Preamble of the Council Framework Decision on the EEW $\S 27$, and preamble of the project of Directive on the EIO $\S 17$.
} 
chance to be admissible within the framework of the procedure in the issuing State because the EEW shall not be a way to avoid protection granted by issuing State law. Then, if a piece of evidence is excluded by the issuing State law (for example correspondence between an lawyer and his client ${ }^{53}$ ), the issuing authority shall not obtain such evidence in a state where it would be admissible, using an EEW ${ }^{54}$. Surprisingly, this condition disappeared in the late instruments. If some authors believe that it still exists, the risks of ill-advised use of mutual recognition remain.

(26) No mutual recognition without harmonization of legislations Considering all this, mutual recognition only seems to work in relation to criminal evidence if national laws are harmonized ${ }^{55}$. In other words, if we want to consider a system of free circulation of evidence within the Union, it is unavoidable that the evidence has to be obtained in accordance with legal conditions that are almost identical in every Member State ${ }^{56}$. If this harmonization is subsidiary in the matter of mutual recognition of judicial decision ${ }^{57}$, it is, on the other hand, essential in the matter of evidence. Mutual recognition is not sufficient to ensure the admissibility of criminal evidence obtained abroad: it goes with the creation of common rules on the admissibility of criminal evidence between member states.

\section{The necessity of creating common rules on the admissibility of evidence in criminal matters between European Union Members States}

(27) Creation and application of common rules - Only the creation of common rules between all the Union's members will ensure the efficiency of mutual recognition and consequently guarantee the admissibility of criminal evidence obtained between member states. The harmonization of the normative systems is to establish analogies or similarities between them, according to concerted goals, and eliminating the differences which are incompatible ${ }^{58}$. The European Parliament and the Council should use the possibility given by Article $82 \S 2$ of the TFEU to establish common rules, which will allow efficient obtainment of criminal evidence and which respects fundamental rights of citizens, in order to minimize differences of legislations and increase the mutual trust between member states. In order to analyze this harmonization in all its aspects, its is necessary to examine first the creation of common rules (1) and then their application (2).

\footnotetext{
${ }^{53}$ French Code de procédure pénale, article 432.

${ }^{54}$ Preamble of the Draft Framework decision of 2003, page 12.

${ }^{55}$ F. Jault-Seseke and J. Lelieur, "Les différences d'approche de l'espace judiciaire européen sur les plans civil et pénal", in L'espace judiciaire européen civil et pénal : regards croisés, Dalloz, collection Thèmes et commentaires, 2009, page 16 ; M. Michel, "L'ordre juridique étatique : un ordre juridique concurrencé ? La question du principe de reconnaissance mutuelle", Annales de droit européen 2004, volume 2, page 31 et seq.

${ }^{56} \mathrm{~S}$. Gless, "Recherche et utilisation des preuves situées à l'étranger", in L'espace judiciaire européen civil et pénal : regards croisés, Dalloz, collection Thèmes et commentaires, 2009, p. 161.

${ }^{57} \mathrm{G}$. Taupiac-Nouvel, Le principe de reconnaissance mutuelle des décisions répressives dans l'Union européenne. Contribution à l'étude d'un modèle de libre circulation des décisions de justice, op. cit., §99 et seq.

${ }^{58}$ A. Weyenbergh, L'harmonisation des législations : condition de l'espace pénal européen et révélateur de ses tensions, éditions de l’Université de Bruxelles, collection Etudes européennes, 2004, § 37.
} 


\section{The creation of common rules on the admissibility of evidence between member States}

(28) A necessary harmonization - The necessity of the harmonization will certainly complicate matters considerably as criminal procedure is even more national than criminal law ${ }^{59}$. Nevertheless, this harmonization - is perfectly acceptable if it has adequate legal grounds (a) and if its area is strictly limited to rules on the admissibility of evidences between member states (b).

\section{a) Common rules' legal grounds}

(29) Model of reference and taking into account national specificities The first question raised is to know whether common rules on the admissibility of criminal evidence between member states should be created ex nihilo or if they can be inspired by existing texts such as the Charter of Fundamental Rights of the European Union or the European Convention of Human Rights. Obviously, it seems possible to follow the example of these texts, provided that the protection of fundamental rights should be at least equal ${ }^{60}$, and that the creation of concrete rules is adapted to the specificity of every evidence ${ }^{61}$. Besides, in order to create a solid project, it is essential to take into account national specificities which are not simply accidental circumstances which could be counterbalanced by the sole wish of cooperation, but on the contrary, real legal traditions that are potentially contradictory.

(30) The degree of protection of EU citizens - On the question of the degree of achievement of those common rules, Article $82 \S 2$ TFEU refers to minimum rules. From both the European and French points of view, those rules will only be successful if they propose a high degree of protection for suspected people in criminal proceedings, failing which the European judicial cooperation will continue to suffer from the lack of confidence between Member States ; and the level of protection of citizens in France will not be sufficient ${ }^{62}$. To simply recopy the principles of the Charter on Fundamental Rights or the European Convention of Human Rights would not actually be a significant enough achievement because these texts failed to compensate for the differences of legislations. In its resolution of 30 November, 2009, on a Roadmap for strengthening procedural rights of suspected or accused persons in criminal proceedings $s^{63}$, the Council indicates that "at the same time, there is room for further action on the part of the European Union to ensure full implementation and respect of Convention standards, and, where appropriate, to ensure consistent application of the applicable standards and to raise existing standards". The creation of common rules on the admissibility of criminal

\footnotetext{
${ }^{59}$ J. Pradel, G. Corstens, G. Vermeulen, Droit pénal européen, op. cit., § 508.

${ }^{60}$ See infra no 30.

${ }^{61}$ See infra no 32.

${ }^{62} \mathrm{~J}$. Lelieur, "L'application de la reconnaissance mutuelle à l'obtention transnationale de evidences pénales dans l'Union européenne : une chance pour un droit probatoire français en crise", op. cit.

${ }^{63}$ Document 2009/C 295/01.
} 
evidence should therefore guarantee a high level of protection of suspected or accused persons.

If they are only minimum rules, Member States will always have the possibility to maintain or create a higher level of protection. Nevertheless, the disadvantage is that a national or a resident of a Member State will use his legal system guarantees, and then will be insecure when submitted to lower standards, even if they are in keeping with European minimum rules ${ }^{64}$. And yet, creation of only minimum rules seems inevitable, in accordance with Article $82 \S 2$ TFEU, which indicates, that they will only be concerned for cross-border crime proceedings, which leads to the question of the scope of these common rules.

\section{b) Common rules' scope}

(31) Limitation to cross-border proceedings - The question of the common rules' scope might be surprising because it is obviously about the admissibility of criminal evidence between Member States. In reality, it is necessary to determine if rules of those proceedings shall be limited to proceedings which have a cross-border dimension or shall, on the contrary, concern all national proceedings ${ }^{65}$.

According to the first concept, harmonisation shall be limited to the proceedings which have a cross-border dimension, particularly to those which lead to mutual recognition of foreign judicial decisions. This harmonisation shall concern all steps of the proceeding, that is to say criminal investigation, judgment and sentence execution. The certitude that the evidence was obtained in conditions which guarantee its quality and the respect of fundamental rights will raise the confidence and make easier mutual recognition.

According to the second concept, harmonisation should, in order to be effective, concern all national procedures, that is to say including purely national proceedings. It means that all criminal proceedings should be harmonised, even those which do not have a cross-border dimension.

It is neither realistic nor desirable to create a European code of criminal proceedings, even if it were only dedicated to criminal evidence. It is more reasonable to limit common rules to the admissibility of common rules in the frame of crossborder procedures ${ }^{66}$. This is provided for by Article $82 \S 2$ of the TFEU, which encourages the establishment of minimum rules "to the extent necessary to facilitate mutual recognition of judgments and judicial decisions and police and judicial cooperation in criminal matters having a cross-border dimension".

\footnotetext{
${ }^{64}$ D. Flore, Droit pénal européen. Les enjeux d'une justice pénale européenne, op. cit., page 311.

${ }^{65}$ On these two conceptions, see D. Flore, Droit pénal européen. Les enjeux d'une justice pénale européenne, op. cit., page 284 et seq. See also C. Morgan, "Le rapprochement des procédures pénales", Revue internationale de droit pénal 2006, page 307 ; A. Weyembergh, "L'harmonisation des procédures pénales au sein de l'union européenne", Archives de politique criminelle $\mathrm{n}^{\circ} 26,2004$, page 37 et seq.

${ }^{66} \mathrm{~J}$. Lelieur says the same thing about the obtention of evidence ("L'application de la reconnaissance mutuelle à l'obtention transnationale de preuves pénales dans l'Union européenne : une chance pour un droit probatoire français en crise", op. cit., § 18).
} 
The choice of limiting the creation of common rules to procedures with a crossborder dimension may cause a fear of differences for guarantees between these procedures and national criminal procedures. It seems ineluctable, and even if this disadvantage is not insignificant, the construction of European criminal law leads systematically to this result.

(32) General principles and specific rules of every evidence - The Green Paper of 2009 already raised the question whether it would be best to adopt general standards applying to all types of evidence or to adopt more specific standards accommodating different types of evidence. Given the characteristics of the different types of evidence, the former approach would be limited to agreeing on general principles while the latter approach would allow for more specific approximation rules. In actual fact, those two approaches should be combined ${ }^{67}$. First, it is desirable to create general principles, to standardize the guarantees which will benefit the persons included in a procedure of judicial cooperation. Secondly, and considering the legality principle, the creation of specific rules according to the kind of evidence seems fair. Those rules shall concern not only the admissibility of criminal evidence, that is to say the way they are obtained, but also the sanctions of their eventual inadmissibility because the systematic application of nullity is not quite appropriate ${ }^{68}$.

The common rules, aiming to guarantee the admissibility of criminal evidence in the twenty-seven Member States, may be divided into several categories. First of all, the distinction between evidence that already exists or which is directly available and that which could not be used ${ }^{69}$. Secondly, common rules may distinguish whether the evidence has been obtained by subjecting individuals to coercive measures or not, because the consequences for these persons' liberties are not the same, and the protection of fundamental rights will not be ensured in the same way. Finally, it is possible to maintain special procedures, for example temporary transfer of persons held in custody, hearing by video or telephone conference, obtaining information related to bank accounts, transactions or controlled deliveries, as proposed by the Directive on the European Investigation.

With the scope of common rules being summarized, we need to see how their implementation might allow the mutual admissibility of such evidence between Member States.

\section{Implementation of common rules on the admissibility of evidence in criminal matters between European Union Member States}

(33) Creation of common rules in order to serve mutual recognition The point of these common rules is to make a piece of evidence admissible in every European Union Member State, so that mutual recognition fully applies.

\footnotetext{
${ }^{67}$ COM (2009) 624 final $§ 4.2$.

${ }^{68}$ For example, in France, it is requiered that the party protected by the violated regulation prove that this violation infringed upon his rights (Articles 171 and 802 of the Code de procédure pénale require a grievance).

${ }^{69}$ This distinction appears in the Council Framework Decision on the EEW.
} 
Evidence may then, in conjunction with a judicial decision, circulate freely. But since mutual recognition seems inevitably limited to judicial decisions ${ }^{70}$, it is necessary to create a jurisdictional control of the admissibility of evidences (a). Recommending such a control is not enough without clarifying its practical details (b).

\section{a) Existence of a judicial control of the admissibility of the evidence}

(34) Control of the respect of law by the executing authority - If the competent authority manages to create a basis of common rules on the admissibility of criminal evidence, obstacles to the mutual recognition previously observed $^{71}$ might be eliminated. But applying mutual recognition directly to the evidence obtained by the cooperation procedure would mean that the issuing State criminal judge would not be competent to control the admissibility of the evidence which has been transferred by the executing State. Then, the admissibility of the evidence may not be controlled, neither by the executing State which would just obtain and transfer the evidence according to the cooperation request, nor by the issuing State which would apply the principle of mutual recognition. Yet, harmonization of criminal procedures does not imply that the executing authority (police for example) respected those rules. While it is one thing to trust the legislation of the partner State, it is another one to trust the executing authority who might violate common rules, and in total impunity because of the lack of judicial control. It would be astonishing that, while the admissibility of criminal evidence obtained in a national procedure is strictly verified, the evidence obtained in another Member State in the frame of a cooperation procedure would not. It is then inevitable to recommend judicial control of the admissibility of such evidence, the functions of which shall now be summarized.

\section{b) Functioning of the jurisdictional control of the admissibility of the evidence}

(35) Application of mutual recognition after the control of admissibility by the executing state - If mutual recognition can apply directly to a decision, it seems dependant on previous judicial control in the matter of evidence. The question is raised: who should perform this control? The issuing State or the executing State? An act of investigation done by the executing authority seems logical for the control to be done by a judge from the executing state; the contrary means a total denial of mutual recognition. Mutual recognition would be about the jurisdictional act deriving from this control. In other words, mutual recognition should be applied not directly to the evidence, but to the decision which declares

\footnotetext{
${ }^{70} \mathrm{G}$. Taupiac-Nouvel, Le principe de reconnaissance mutuelle des décisions répressives dans l'Union européenne. Contribution à l'étude d'un modèle de libre circulation des décisions de justice, $\$ 184$ et seq.

71 See supra no 19 et seq.
} 
the evidence admissible. It is then a classic case of mutual recognition of repressive decisions, allowing free circulation of justice decisions.

(36)The problem of potential application of a foreign law - Despite the existence of common rules on the obtention of criminal evidence, if the possibility for the issuing State to require rules according to which the evidence shall be obtained is maintained ${ }^{72}$-a possibility which is absolutely conceivable because the common rules are supposed to be minimal rules-, the criminal judge from the executing state would then be confined to the application of a foreign law. He will have to verify if the evidence was obtained with the respect to the modalities specified by the issuing authority and the guarantees granted by the issuing State legislation, a job which might be even harder if the national law or the jurisprudence needs to be interpreted. In addition, if the application and control of foreign law were admissible, which appeal would be offered to the defence who would question the correct application by the executing state before the judicial authority in the issuing State ${ }^{73}$ ? This question highlights the potential difficulties in the application of such control. Nevertheless, it seems inevitable in the functioning of mutual recognition. This is why common rules need to be as precise as possible, and offer a high level of protection, in order that the Member States' scope to grant additional rights be limited, and then the manner in which evidence is obtained would be truly harmonized, or even unified.

(37) Conclusion - If mutual recognition is an efficient instrument of judicial cooperation in criminal matters, it cannot apply to evidences per se. First, before settling the matter of the admissibility of evidence between States Members, it is essential to legislate on its obtention. As suggested by the draft directive on the European Investigation Order in criminal matters, it is necessary to create a single instrument for gathering evidence, in order to put an end to the dispersion of actual instruments, which are not always used. The creation of such an instrument then needs to be accompanied by the ediction of common rules on the admissibility of evidence in criminal matters because, as stated earlier, it is pointless to transfer a piece of evidence if it cannot be used afterwards before a criminal court. Competent authorities should use the powers conferred by Article $82 \S 2$ of the TFUE in order to create common rules in this area, rules that should offer a high level of protection for European citizens. Despite this harmonisation, it is desirable to establish a jurisdictional control of the evidence by a judge of the executing State, in order to verify that the executing authority gathered the evidence in accordance with existing rules. The issuing State shall recognize the decision taken by this judge which guarantees the admissibility of this evidence because the method of mutual recognition can only apply in an indirect way in matters of evidence. It is only with all these compromises that the admissibility of criminal evidence will be ensured.

\footnotetext{
${ }^{72}$ See supra no 14 et seq.

${ }^{73}$ V. Malabat and alii, "La dimension internationale de la justice pénale », op. cit., page 189.
} 